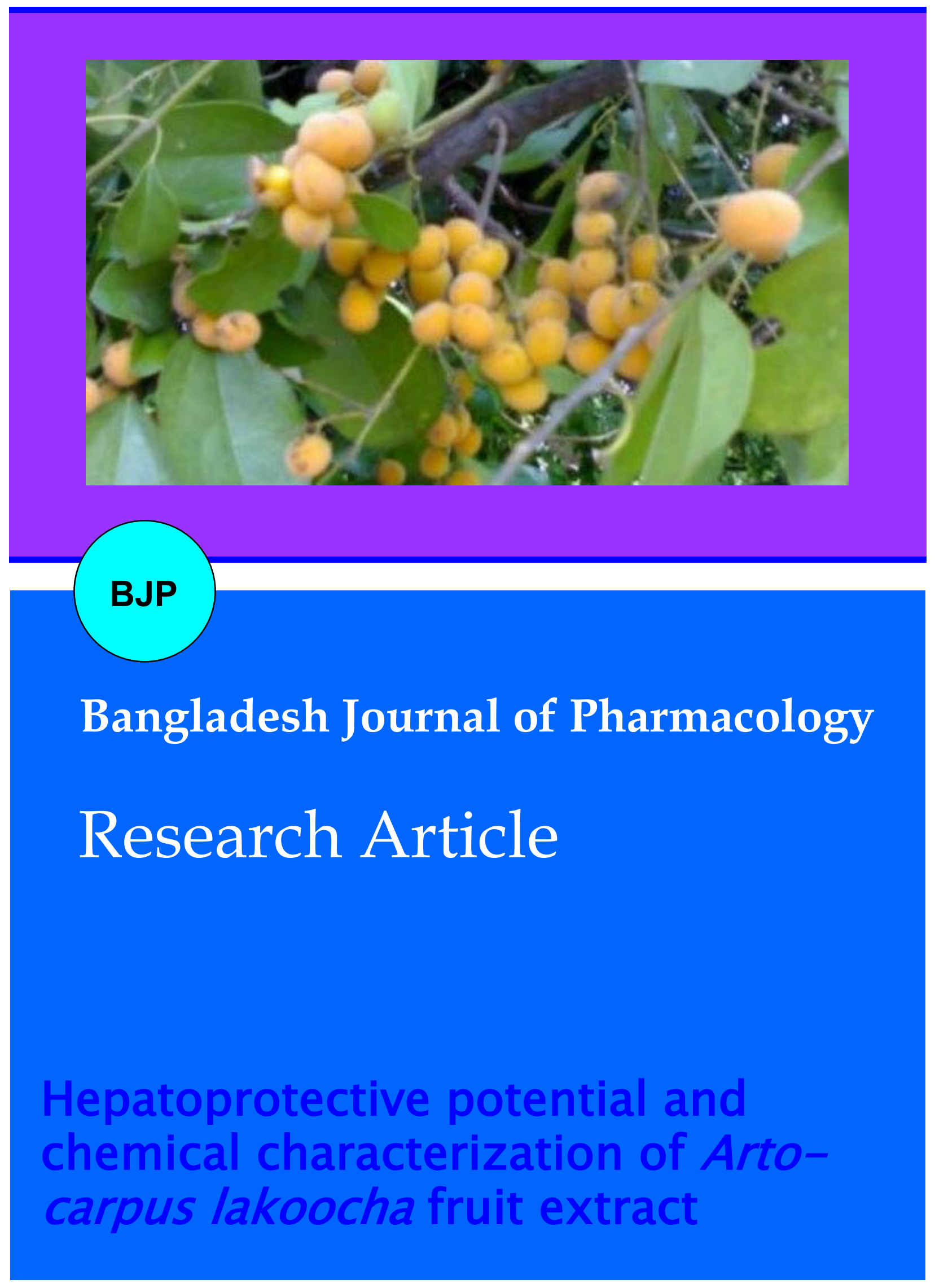




\title{
Hepatoprotective potential and chemical characterization of Artocarpus lakoocha fruit extract
}

\author{
Mohammad Saleem, Ammara Asif, Muhammad Furqan Akhtar and Ammara Saleem \\ Department of Pharmacology, Faculty of Pharmaceutical Sciences, Government College University Faisalabad, \\ Faisalabad, Pakistan.
}

\begin{tabular}{|c|c|}
\hline \multicolumn{2}{|l|}{ Article Info } \\
\hline Received: & 27 October 2017 \\
\hline Accepted: & 20 March 2018 \\
\hline Available Online: & 20 March 2018 \\
\hline \multicolumn{2}{|c|}{ DOI: 10.3329/bjp.v13i1.34117 } \\
\hline \multicolumn{2}{|c|}{$\begin{array}{l}\text { Cite this article: } \\
\text { Saleem M, Asif A, Akhtar MF, Saleem } \\
\text { A. Hepatoprotective potential and } \\
\text { chemical characterization of Artocar- } \\
\text { pus lakoocha fruit extract. Bangladesh J } \\
\text { Pharmacol. 2018; 13: 90-97. }\end{array}$} \\
\hline
\end{tabular}

\begin{abstract}
Artocarpus lakoocha fruits are widely consumed as food. The study was aimed at evaluating its hepatoprotective activity and chemical constituents. The extract was analysed by HPLC for the presence of flavonoids and phenolic compounds. Hepatoprotective potential was determined in mice following 8 days of extract or silymarin (standard therapy) administration. Hepatotoxicity was induced by administration of paracetamol $(500 \mathrm{mg} / \mathrm{kg})$. The blood and liver of treated and untreated mice were collected 24 hours post-paracetamol intoxication. HPLC analysis confirmed the presence of chromatotropic acid, quercetin, gallic acid, vanillic acid, cinnamic acid, ferulic acid and kaempferol. Acute toxicity study showed no observed effect at more than $2,000 \mathrm{mg} / \mathrm{kg}$. The fruit extract prevented the rise in liver function tests and paracetamol related histopathological alterations. The hepatoprotective activity of extract was dose-dependent. This study confirms the preventive effect of methanolic extract of monkey jack fruits against paracetamol-induced liver toxicity.
\end{abstract}

\section{Introduction}

Liver is a vital organ for metabolism and plays a pivotal role in detoxification and elimination of drugs. Hepatic damage occurs in response to xenobiotics, medications, alcohol and viral infections (Saleem et al., 2016). Longterm exposure to toxins produces reactive oxygen species (ROS) which may lead to oxidative stress, lipid peroxidation and cellular damage through alteration of metabolic processes in hepatocytes (Akhtar et al., 2011).

Allopathic drugs can rarely stimulate the liver function (Akhtar et al., 2016a). Therefore, a huge number of herbal drugs have been investigated for their ability to regenerate and protect hepatocytes (Ijaz et al., 2017; Qadir and Ahmad, 2017; Rehman et al., 2017; Ishtiaq et al., 2017; Sunil Kumar et al., 2017; Ullah et al., 2016). According to WHO, about 4 billion people use herbal medicines for primary health care (Akhtar et al., 2016c).
Ayurvedic medicines have been used for the treatment of liver diseases for centuries and are claimed to offer significant relief against hepatitis and other acute medical conditions (Sharif et al., 2017).

Artocarpus lakoocha, also called monkey Jack, belongs to the family Moraceae and is native to sub-Himalayan areas of India, Nepal, Pakistan, South China and SouthEast Asia (Raghavendra et al., 2012). Fruit pulp of $A$. lakoocha is edible and traditionally used as a tonic for liver. Plant leaves are used for the management of cirrhosis, tuberculosis, ulcer, wound healing, diabetes mellitus and hypertension, while seeds are used for the treatment of diarrhea (Joshi and Joshi, 2000). Plant roots are used for the inflammation, contraception, anemia, asthma, dermatitis and cough while the sap is used as ointment and cooking oil (Jagtap and Bapat, 2010). The plant is known to exhibit various in vitro and in vivo pharmacological activities such as antibacterial, anti- 
oxidant, anthelmintic, antiviral, skin whitening, antiproliferative, anti-herpes, insecticidal, inhibition of aglucosidase and neuraminidase, and cytotoxic activities against different cancer cell lines (Chatsumpun et al., 2016).

Literature survey reveals that no scientific study has been carried out regarding the hepatoprotective potential of A. lakoocha fruits. Hence, the focus of this study was to evaluate the scientific basis for the use of a methanolic extract of $A$. lakoocha fruits for hepatoprotection and identification of its chemical constituents.

\section{Materials and Methods}

\section{Collection of plant and extraction}

Fresh fruits of A. lakoocha were collected in April-May 2016 from Lahore district, Pakistan. Identification of the plant was carried out at the University of Agriculture, Faisalabad and voucher number (45-1-2017) was assigned for future reference. The shade dried fruits were powdered with mechanical grinder. Methanolic extract of $A$. lakoocha was prepared by maceration followed by drying with a rotary evaporator (ColeParmer $\left.^{\circledR}, \mathrm{UK}\right)$ under reduced pressure. The extract was preserved in an airtight container at $-20^{\circ} \mathrm{C}$ until further use.

\section{Chemicals}

All chemicals used in the study were of analytical grade. Alanine aminotransferase (ALT) test kit (Medichem ${ }^{\circledR}$, Syia), aspartate aminotransferase (AST) test kit (Medichem ${ }^{\circledR}$, Syria), alkaline phosphatase (ALP) test kit (Erba Mannhcim ${ }^{\circledR}$, India) and total bilirubin test kit (CliniChem ${ }^{\circledR}$, USA) were used.

\section{Phytochemical evaluation}

The plant extract was subjected to qualitative preliminary phytochemical analysis to determine the presence of flavonoids, tannins, saponins, terpenoids, alkaloids, glycosides, steroids, proteins, carbohydrates and anthraquinones according to the standard methods described previously (Ahmed et al., 2017).

HPLC analysis was carried out to determine the hepatoprotective constituents in methanolic extract. $50 \mathrm{mg}$ extract was dissolved in $5 \mathrm{~mL}$ distilled water and $12 \mathrm{~mL}$ methanol followed by incubation for $5 \mathrm{~min}$. $6 \mathrm{~mL}$ distilled water was added to it and incubated again for $5 \mathrm{~min}$. Then, $10 \mathrm{~mL} 15 \mathrm{M} \mathrm{HCl}$ was added and the solution was placed in an incubator at $90^{\circ} \mathrm{C}$ for 2 hours to break glycosidic linkages. The solution was filtered with $0.2 \mu \mathrm{m}$ syringe filter. The sample was injected on HPLC shim-pack CLC-ODS (C-18) column. Mobile phase was acetonitrile: dichloromethane: methanol (60:20:20) and flow rate was adjusted to $1 \mathrm{~mL} / \mathrm{min}$. Phenolic and flavonoid compounds were detected with a UV-Vis detector at $280 \mathrm{~nm}$ whereas kaempferol was detected at $248 \mathrm{~nm}$ (Saleem et al., 2014).

\section{In vivo studies}

The extract and silymarin solutions were prepared in distilled water. Paracetamol suspension was made in $0.5 \% \mathrm{w} / \mathrm{v}$ gum tragacanth in normal saline (Khorsandi and Orazizadeh, 2008). White Swiss albino mice weighing 25-35 g were acquired and kept in the animal house of the Faculty of Pharmaeutical Sciences, Government College University Faisalabad. Mice were housed in separate cages at $25 \pm 2{ }^{\circ} \mathrm{C}$ in a 12 hours light-dark cycle. Mice had free access to standard laboratory pellet diet and fresh water during the study.

\section{Acute toxicity study}

Mice of either sex were randomly divided into groups of five animals. Normal control group received water only. Methanolic extract of A. lakoocha was administered at $250-2000 \mathrm{mg} / \mathrm{kg}$ to different groups. Toxic symptoms and mortality were observed in all animals for 72 hours post-treatment (Shanmugasundaram and Venkataraman, 2006).

\section{Paracetamol-induced hepatotoxicity}

For hepatoprotective activity in mice, distilled water was administered to normal control group. Mice in disease control group also received distilled water until the induction of hepatotoxicity with paracetamol. Mice in reference control group received silymarin $100 \mathrm{mg} /$ $\mathrm{kg} /$ day orally for 8 days. The other three groups orally received 125, 250 or $500 \mathrm{mg} / \mathrm{kg} /$ day methanolic extract of $A$. lakoocha for 8 days (Okokon et al., 2016). On the $8^{\text {th }}$ day, paracetamol $(500 \mathrm{mg} / \mathrm{kg})$ was orally administered to all groups except normal control group, 3 hours after administration of daily therapy.

\section{Assessment of liver biochemical and histopathological parameters}

Mice were fasted overnight. Blood was collected from mice by heart puncture 24 hours post paracetamol treatment. Mice were killed by cervical dislocation under chloroform anesthesia. The changes in ALT, AST, ALP and total bilirubin were determined by using commercial kits.

The mice liver were isolated, washed with normal saline and kept in $10 \%$ formalin solution. The tissues were embedded in paraffin wax and sectioned with a microtome. Hematoxylin and eosin staining was performed and histopathological changes in mice liver were observed under light microscope (Sharif et al., 2016).

\section{Statistical analysis}

Results were presented as mean \pm standard error and analyzed by one-way ANOVA followed by Dunnett's multiple comparisons test using GraphPad Prism ${ }^{\circledR}$ software. 


\section{Results}

It was found that methanolic extract of A. lakoocha was dark brown in color and the \%yield was $7.27 \%$.

\section{Phytochemical evaluation}

Qualitative phytochemical analysis of fruit extract confirmed the presence of flavonoids, tannins, terpenoids, saponins, glycosides, alkaloids and steroids. But proteins and carbohydrates were absent. HPLC chromatograms of the methanolic extract showed presence of chromatotropic acid, quercetin, gallic acid, vanillic acid, cinnamic acid, ferulic acid and kaempferol (Figure 1). Retention times and quantities of different phytochemicals detected in A. lakoocha are shown in Table I.

\section{Acute toxicity study}

Acute toxicity assessment in albino mice showed that

\begin{tabular}{|lccc|}
\hline \multicolumn{4}{|c|}{ Table I } \\
\hline Compounds detected in methanol extract of Arto- \\
carpus lakoocha fruits \\
\hline $\begin{array}{l}\text { Compound } \\
\text { name }\end{array}$ & $\begin{array}{c}\text { Retention } \\
\text { time }\end{array}$ & $\begin{array}{c}\text { Area } \\
(\%)\end{array}$ & $\begin{array}{c}\text { Quantity } \\
(\mu \mathrm{g} / \mathrm{g})\end{array}$ \\
\hline Kaempferol & 1.7 & 94.9 & 2124.7 \\
Chromato- & 2.3 & 1.4 & 21.6 \\
tropic acid & & & \\
Quercetin & 2.9 & 1.2 & 2.5 \\
Gallic acid & 4.6 & 10.6 & 33.4 \\
Vanillic acid & 13.8 & 24.0 & 40.9 \\
Ferulic acid & 22.6 & 2.8 & 23.7 \\
Cinnamic acid & 25.7 & 3.8 & 11.1 \\
\hline
\end{tabular}

the extract had not shown any signs and symptoms of toxicity up to a dose of $2000 \mathrm{mg} / \mathrm{kg}$ and the extract was

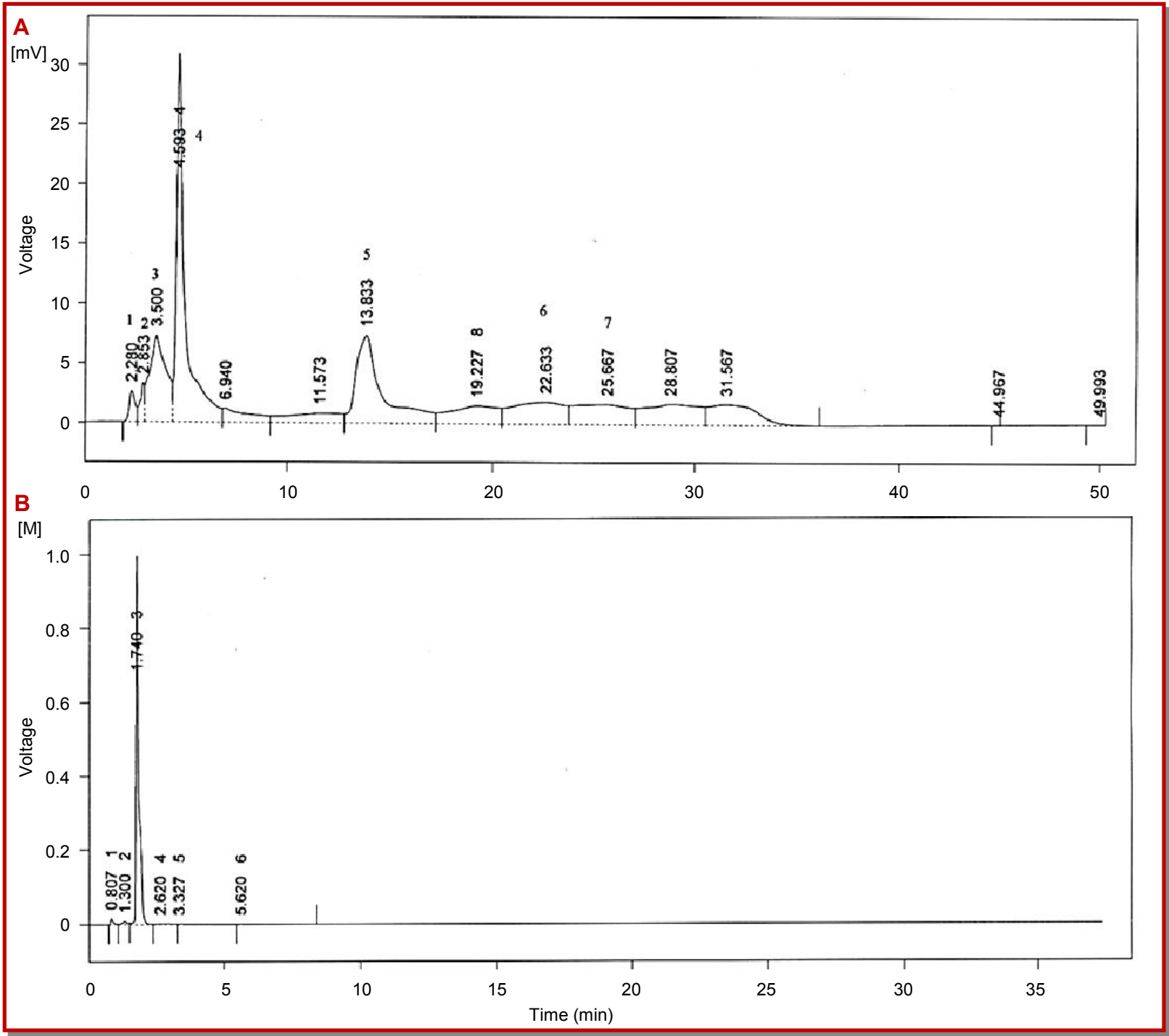

Figure 1: (A) HPLC Chromatogram of methanolic extract of Artocarpus lakoocha showing (1) ethanol, (2) chromatotropic acid, (3) quercetin, (4) gallic acid, (5) vanillic acid, (6) ferulic acid and (7) cinnamic acid; (B) kaempferol 
Table II

\begin{tabular}{|c|c|c|c|c|}
\hline Groups & Serum albumin & ALT & AST & ALP \\
\hline Normal control & $0.4 \pm 0.03$ & $116.8 \pm 3.2$ & $233.4 \pm 5.6$ & $258.4 \pm 18.3$ \\
\hline Disease control & $\begin{array}{l}0.6 \pm 0.03 \\
(42.0 \%) \uparrow a\end{array}$ & $\begin{array}{r}265 \pm 16.4 \\
(126.9 \%) \uparrow^{a}\end{array}$ & $\begin{array}{r}422.6 \pm 12.0 \\
(81.1 \%) \uparrow^{a}\end{array}$ & $\begin{array}{r}232.2 \pm 4.9 \\
(10.1 \%) \downarrow^{a}\end{array}$ \\
\hline Silymarin pre-treatment & $\begin{array}{r}0.4 \pm 0.01^{\mathrm{b}} \\
(27.0 \%) \downarrow\end{array}$ & $\begin{array}{r}214.8 \pm 1.3^{\mathrm{b}} \\
(19.0 \%) \downarrow\end{array}$ & $\begin{array}{r}319.3 \pm 37.5^{\mathrm{b}} \\
(24.5 \%) \downarrow\end{array}$ & $\begin{array}{r}247 \pm 12.5 \\
(6.4 \%) \uparrow\end{array}$ \\
\hline $\begin{array}{l}\text { A. lakoocha fruit extract } \\
125 \mathrm{mg} / \mathrm{kg} \text { pre-treatment }\end{array}$ & $\begin{array}{r}0.5 \pm 0.03 \text { n.s } \\
(15.46 \%) \downarrow\end{array}$ & $\begin{array}{r}231.4 \pm 8.7 \mathrm{a} \\
(12.7 \%) \downarrow\end{array}$ & $\begin{array}{r}394.4 \pm 5.5 \\
(6.7 \%) \downarrow\end{array}$ & $\begin{array}{r}262.6 \pm 11.4 \\
(13.2 \%) \uparrow\end{array}$ \\
\hline $\begin{array}{l}\text { A. lakoocha fruit extract } \\
250 \mathrm{mg} / \mathrm{kg} \text { pre-treatment }\end{array}$ & $\begin{array}{r}0.5 \pm 0.02^{\text {n.s }} \\
\quad(17.3 \%) \downarrow\end{array}$ & $\begin{array}{r}223.4 \pm 3.9 \mathrm{~b} \\
(15.7 \%) \downarrow\end{array}$ & $\begin{array}{r}345.4 \pm 9.6^{\mathrm{a}} \\
(18.3 \%) \downarrow\end{array}$ & $\begin{array}{r}202.4 \pm 8.2 \\
(12.8 \%) \downarrow\end{array}$ \\
\hline $\begin{array}{l}\text { A. lakoocha fruit extract } \\
500 \mathrm{mg} / \mathrm{kg} \text { pre-treatment }\end{array}$ & $\begin{array}{r}0.5 \pm 0.05^{\mathrm{a}} \\
(22.7 \%) \downarrow\end{array}$ & $\begin{array}{r}219.2 \pm 6.6^{\mathrm{b}} \\
(17.3 \%) \downarrow\end{array}$ & $\begin{array}{r}331.8 \pm 18.8^{\mathrm{b}} \\
(21.5 \%) \downarrow\end{array}$ & $\begin{array}{r}181.6 \pm 10.6 \mathrm{a} \\
(21.8 \%) \downarrow\end{array}$ \\
\hline
\end{tabular}

\begin{tabular}{|c|c|c|c|c|c|c|c|}
\hline \multicolumn{8}{|c|}{ Table III } \\
\hline \multicolumn{8}{|c|}{ Protective effect of A. lakoocha fruit extract on liver histology against paracetamol-induced hepatic lesions } \\
\hline $\begin{array}{l}\text { SL. } \\
\text { No }\end{array}$ & Label & $\begin{array}{l}\text { Portal inflam- } \\
\text { mation }\end{array}$ & $\begin{array}{l}\text { Lobular in- } \\
\text { flammation }\end{array}$ & $\begin{array}{l}\text { Swell- } \\
\text { ing }\end{array}$ & $\begin{array}{l}\text { Fatty } \\
\text { change }\end{array}$ & $\begin{array}{l}\text { Spotty ne- } \\
\text { crosis }\end{array}$ & $\begin{array}{l}\text { Geographic } \\
\text { necrosis }\end{array}$ \\
\hline 1 & Distilled water & - & $\stackrel{+}{+}$ & - & - & - & - \\
\hline 2 & Disease control & $\begin{array}{c}++ \\
(\mathrm{L}, \mathrm{N})\end{array}$ & $\begin{array}{c}++ \\
(\mathrm{L}, \mathrm{N})\end{array}$ & + & + & ++ & +++ \\
\hline 3 & $\begin{array}{l}\text { Silymarin } \\
100 \mathrm{mg} / \mathrm{kg}\end{array}$ & $\stackrel{+}{(\mathrm{L}, \mathrm{N})}$ & $\stackrel{+}{(\mathrm{L}, \mathrm{N})}$ & - & - & - & - \\
\hline 4 & $\begin{array}{l}\text { Pretreatment with } \\
\text { A.lakoocha fruit extract } \\
125 \mathrm{mg} / \mathrm{kg}\end{array}$ & $\begin{array}{c}++ \\
(\mathrm{L}, \mathrm{N})\end{array}$ & $\begin{array}{c}+++ \\
(\mathrm{L}, \mathrm{N})\end{array}$ & + & + & ++ & +++ \\
\hline 5 & $\begin{array}{l}\text { Pretreatment with } A \text {. } \\
\text { lakoocha fruit extracts } \\
250 \mathrm{mg} / \mathrm{kg}\end{array}$ & $\begin{array}{c}++ \\
(\mathrm{L}, \mathrm{N})\end{array}$ & $\begin{array}{c}++ \\
(\mathrm{L}, \mathrm{N})\end{array}$ & + & + & + & $\begin{array}{l}+ \\
\text { (around central } \\
\text { vein) }\end{array}$ \\
\hline 6 & $\begin{array}{l}\text { Pretreatment with } A \text {. } \\
\text { lakoocha } 500 \mathrm{mg} / \mathrm{kg}\end{array}$ & $\stackrel{+}{+}$ & $\stackrel{+}{(\mathrm{L}, \mathrm{N})}$ & + & - & - & - \\
\hline
\end{tabular}

assumed to be safe at $2000 \mathrm{mg} / \mathrm{kg}$ dose.

\section{Effect on liver biochemical parameters}

Administration of paracetamol significantly increased the level of ALT, AST and albumin in disease control mice. However, paracetamol did not exhibit an increase in ALP. Pre-treatment with the extract significantly prevented the rise in ALT as compared to disease control group. Silymarin pre-treatment also prevented the rise in serum ALT as compared to disease control group. Pre-treatment with either dose of the extract significantly prevented the rise in AST as compared to disease control group. The effect of extract on serum AST was statistically comparable to silymarin pretreatment. Pre-treatment with the extract also preven- ted the rise in serum ALP at $500 \mathrm{mg} / \mathrm{kg}$ dose as compared to disease control group (Table II).

\section{Protective effect on liver histology}

Hepatoprotective effect of the extract was also evident from the histopathological evaluation of mice liver. The liver of normal control mice showed typical cellular architecture, uniform cytoplasm and a central vein. Treatment with paracetamol instigated a moderate portal and lobular inflammation, steato-hepatitis and spotty and marked geographic necrosis in disease control group (Figure 2).

Silymarin treated mice showed mild infiltration of leukocytes and neutrophils without any sign of swe- 


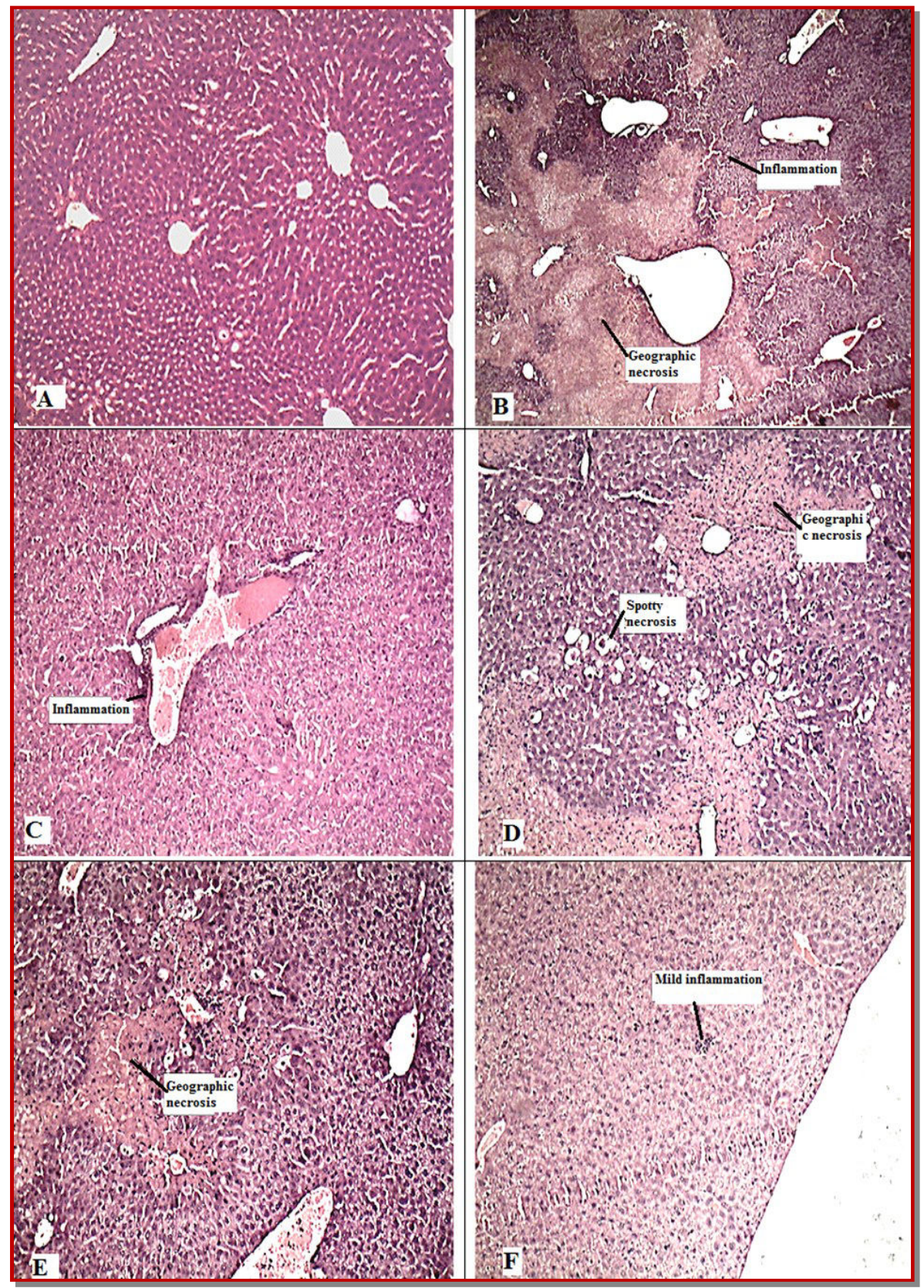

Figure 2: The preventive effect of the methanolic extract of Artocarpus lakoocha against paracetamol-induced toxicity in albino mice livers (10x magnification). (A) Normal control mouse liver showed normal liver parenchyma. No swelling, fatty changes or necrosis was observed; (B) Paracetamol-treated disease control group showing geographic necrosis and surrounding inflammation; (C) A liver section of silymarin pretreated mice showed mild inflammation of parenchyma; (D) A liver section of mice pre-treated with A. lakoocha $(125 \mathrm{mg} / \mathrm{kg})$ showed geographic necrosis, inflammation, swelling of hepatocytes and fatty changes; (E) The liver section of mice pretreated with A. lakoocha $(250 \mathrm{mg} / \mathrm{kg})$ showing patchy geographic necrosis and inflammation; (F) The liver section of mice pre-treated with A. lakoocha $(500 \mathrm{mg} / \mathrm{kg}$ ) showed mild inflammation. Necrosis, fatty change or swelling of hepatocytes was not observed 
lling, steato-hepatitis and necrosis. The extract treated mice showed mild swelling, steato-hepatitis, moderate neutrophil and leukocyte infiltration and geographic necrosis at 125 and $250 \mathrm{mg} / \mathrm{kg} /$ day dose. However, pretreatment with $500 \mathrm{mg} / \mathrm{kg}$ extract did not show any signs of steato-hepatitis and necrosis. The hepatoprotective effect of extract was dose-dependent (Figure 2). The extract also preserved the normal architecture of mice liver against paracetamol induced toxicity. The hepatoprotective effect of lakucha extract was similar to silymarin (Bahmani et al., 2015). The histopathological findings are summarized in Table III.

\section{Discussion}

Hepatotoxicity can occur directly or indirectly due to ROS (Akhtar et al., 2016b). It is usually associated with a decrease in activity of endogenous anti-oxidant enzymes (Sharif et al., 2016). Foods are rich source of natural anti-oxidants such as phenols and flavonoids. Various food extracts have been shown to protect against toxicant induced hepatotoxicity due to the presence of these phytochemicals (Hurkadale et al., 2012). Paracetamol causes centro-lobular necrosis in men and rodents at high doses through the production of ROS (Parmar et al., 2010). Excessive production of ROS causes the disturbances of calcium homeostasis, disrupts the mitochondrial functioning and leads to cell death. Hepatocellular necrosis is manifested by an increase in liver function biomarkers and histopathological changes (Hurkadale et al., 2012). ALT is a more specific indicator of acute damage to liver parenchyma than AST (Okokon et al., 2016).

This study showed the presence of flavonoids, tannins, terpenoids, saponins, glycosides, alkaloids and steroids in lakucha fruit extract. The results were supported by a previous report of the presence of these primary and secondary metabolites in A. lakoocha fruit pericarp (Kumar et al., 2010).

The study testified the presence of chromatotropic acid, quercetin, gallic acid, vanillic acid, cinnamic acid, ferulic acid and kaempferol in methanolic extract of lakucha fruits. Previous studies have reported other phytochemicals such as artocarpine, artocarpetin and agglutinin in lakucha fruits (Shajib et al., 2013). Among the compounds identified in this study, quercetin, gallic acid and kaempferol have been shown to act as natural anti-oxidants and hepatoprotective agents (Saleem et al., 2014). Quercetin is a flavonoid that prevents oxidative damage, nitric oxide formation and hepatocellular necrosis (Pavanato et al., 2003). Kaempferol reduces the oxidative stress and enhances the antioxidant defense mechanisms (Wang et al., 2015). Phenolic compounds such as gallic acid, has potent anti -oxidant activity via inhibition of ROS, lipid peroxidation and elevation of liver anti-oxidant enzymes (Tung et al., 2009).

The effect of fruit extract on ALT, AST and ALP was statistically comparable to silymarin at $500 \mathrm{mg} / \mathrm{kg}$. Previous studies had shown in vivo anti-oxidant activity of quercetin, gallic acid and kaempferol (Saleem et al., 2014) (Ali et al., 2013). So, the hepatoprotective potential of lakucha fruits may be attributed to the presence of quercetin, gallic acid and kaempferol.

The hepatoprotective effect of lakucha extract was similar to silymarin (Bahmani et al., 2015). The results indicate that the extract assisted to maintain the membrane integrity of hepatocytes against paracetamol intoxication (Rehman et al., 2015). It can be proposed that the pretreatment with the extract reduced paracetamol-induced lipid peroxidation due to the presence of natural anti-oxidants such as quercetin, gallic acid and kaempferol (Weng et al., 2011).

\section{Conclusion}

The current study confirms the significant hepatoprotective activity of $A$. lakoocha fruit extract against paracetamol intoxication in mice. Protective effect of the plant extract may be attributed to the metabolites such as quercetin, gallic acid and kaempferol. Hence, this study rationalizes the conventional use of lakucha fruits for preventing liver disorders.

\section{Funding Agency}

This work was not funded by any funding agency.

\section{Ethical Issue}

The study was approved and carried out according to the guidelines of the Institutional ethics committee of Government College University Faisalabad.

\section{Conflict of Interest}

Authors declare that they have no conflict of interest.

\section{References}

Ahmed S, Saeed-Ul-Hassan S, Islam M, Qureshi F, Waheed I, Munawar I. Anti-oxidant activity of Pistachia khinjuk supported by phytochemical investigation. Acta Pol Pharm. 2017; 74: 173-78.

Akhtar B, Ashraf M, Javeed A, Sharif A, Akhtar MF, Saleem A. 
Analgesic, antipyretic and antiinflammatory activities of Grewia asiatica fruit extracts in albino mice. Acta Pol Pharm. 2016a; 73: 983-89.

Akhtar M, Rabbani M, Sharif A, Akhtar B, Saleem A, Murtaza G. Formulation and characterization of modified release tablets containing isoniazid using swellable polymers. Afr J Tradit Complement Altern Med. 2011; 8: 250-59.

Akhtar MF, Ashraf M, Anjum AA, Javeed A, Sharif A, Saleem A, Akhtar B. Textile industrial effluent induces mutagenicity and oxidative DNA damage and exploits oxidative stress biomarkers in rats. Environ Toxicol Pharmacol. 2016b; 41: 180-86.

Akhtar MF, Saleem A, Sharif A, Akhtar B, Nasim MB, Peerzada S, Raza M, Ijaz H, Ahmed S, Shabbir M, Ali S. Genotoxic and cytotoxic action potential of Terminalia citrina, a medicinal plant of ethnopharmacological significance. EXCLI J. 2016c; 15: 589-98.

Ali M, Qadir MI, Saleem M, Janbaz KH, Gul H, Hussain L, Ahmad B. Hepatoprotective potential of Convolvulus arvensis against paracetamol-induced hepatotoxicity. Bangladesh J Pharmacol. 2013; 8: 300-04

Bahmani M, Shirzad H, Rafieian S, Rafieian-Kopaei M. Silybum marianum: Beyond hepatoprotection. J Evidencebased Complement Altern Med. 2015; 20: 292-301.

Chatsumpun N, Chuanasa T, Sritularak B, Lipipun V, Jongbunprasert V, Ruchirawat S. Oxyresveratrol: Structural modification and evaluation of biological activities. Molecules 2016; 21: 489.

Hurkadale PJ, Shelar PA, Palled SG, Mandavkar YD, Khedkar AS. Hepatoprotective activity of Amorphophallus paeoniifolius tubers against paracetamol-induced liver damage in rats. Asian Pacific J Trop Biomed. 2012; 2: S238S42.

Ijaz H, Tulain UR, Qureshi J, Danish Z, Musayab S, Akhtar MF. Nigella sativa (Prophetic medicine): A review. Pakistan J Pharm Sci. 2017; 30: 229-34.

Ishtiaq S, Khan Afridi M, Masood N. Amelioration of isoniazid and rifampicin-induced liver toxicity by Amaranthus graecizans subsp. silvestris in rat. Bangladesh J Pharmacol. 2017; 12: 354-58.

Jagtap U, Bapat V. Artocarpus: A review of its traditional uses, phytochemistry and pharmacology. J Ethnopharmacol. 2010; 129: $142-66$.

Joshi AR, Joshi K. Indigenous knowledge and uses of medicinal plants by local communities of the Kali Gandaki Watershed Area, Nepal. J Ethnopharmacol. 2000; 73: 175-83.

Khorsandi L, Orazizadeh M. Protective effect of Curcuma longa extract on acetaminophen-induced nephrotoxicity in mice. Daru 2008; 16: 155-59.

Kumar MS, Kumar MR, Bharath AC, Kumar HV, Kekuda TP, Nandini KC, Rakshitha MN, Raghavendra HL. Screening of selected biological activities of Artocarpus lakoocha Roxb (Moraceae) fruit pericarp. J Basic Clin Pharm. 2010; 1: 239.

Okokon JE, Bawo MB, Mbagwu HO. Hepatoprotective activity of Mammea africana ethanol stem bark extract. Avicenna J
Phytomed. 2016; 6: 248.

Parmar SR, Vashrambhai PH, Kalia K. Hepatoprotective activity of some plants extract against paracetamol induced hepatotoxicity in rats. J Herbal Med Toxicol. 2010; 4: 101-06.

Pavanato A, Tuñón MJ, Sánchez-Campos S, Marroni CA, Llesuy S, González-Gallego J, Marroni N. Effects of quercetin on liver damage in rats with carbon tetrachloride-induced cirrhosis. Dig Dis Sci. 2003; 48: 824-29.

Qadir M, Ahmad Z. Advances in hepatoprotective medicinal plants research. Bangladesh J Pharmacol. 2017; 12: 229-42.

Raghavendra $\mathrm{H}$, Mallikarjun $\mathrm{N}$, Venugopal T, HS AK. Elemental composition, anticariogenic, pancreatic lipase inhibitory and cytotoxic activity of Artocarpus lakoocha Roxb pericarp. Int J Drug Dev Res. 2012; 4: 330-36.

Rehman A, Liaqat M, Asghar R, Syed N. Evaluation of methanolic extract of Phragmites karka on carbon tetrachlorideinduced liver fibrosis in rat. Bangladesh J Pharmacol. 2017; 12: $276-81$

Rehman JU, Aktar N, Khan MY, Ahmad K, Ahmad M, Sultana $\mathrm{S}$, Asif HM. Phytochemical screening and hepatoprotective effect of Alhagi maurorum Boiss (Leguminosae) against paracetamol-induced hepatotoxicity in rabbits. Trop J Pharm Res. 2015; 14: 1029-34.

Saleem A, Akhtar M, Mushtaq M, Saleem M, Muhammad S, Akhtar B. Current trends in the treatment of hepatitis C: interventions to avoid adverse effects and increase effectiveness of anti-HCV drugs. EXCLI J. 2016; 15: 578-88.

Saleem M, Ahmed B, Qadir MI, Rafiq M, Ahmad M, Ahmad B. Hepatoprotective effect of Chenopodium murale in mice. Bangladesh J Pharmacol. 2014; 9: 124-28.

Shajib MT, Kawser M, Miah MN, Begum P, Bhattacharjee L, Hossain A, Fomsgaard IS, Islam SN. Nutritional composition of minor indigenous fruits: Cheapest nutritional source for the rural people of Bangladesh. Food Chem. 2013; 140: 46670 .

Shanmugasundaram P, Venkataraman S. Hepatoprotective and anti-oxidant effects of Hygrophila auriculata (K. Schum) Heine Acanthaceae root extract. J Ethnopharmacol. 2006; 104: 124-28.

Sharif A, Akhtar MF, Akhtar B, Saleem A, Manan M, Shabbir M, Ashraf M, Peerzada S, Ahmed S, Raza M. Genotoxic and cytotoxic potential of whole plant extracts of Kalanchoe laciniata by Ames and MTT assay. EXCLI J. 2017; 16: 593-601.

Sharif A, Ashraf M, Javeed A, Anjum AA, Akhtar MF, Akhtar B. Oxidative stress responses in Wistar rats on subacute exposure to pharmaceutical wastewater. Environ Sci Pollut Res. 2016; 23: 24158-65.

Sunil Kumar K., Rajakrishnan R., Thomas J, Reddy G. Hepatoprotective effect of Helicanthus elastica. Bangladesh J Pharmacol. 2016; 11: 525-30.

Tung YT, Wu JH, Huang CC, Peng HC, Chen YL, Yang SC, Chang ST. Protective effect of Acacia confusa bark extract and its active compound gallic acid against carbon tetrachlorideinduced chronic liver injury in rats. Food Chem Toxicol. 2009; 47: 1385-92 
Ullah I, Khan J, Adhikari A, Shahid M. Hepatoprotective effect of Monotheca buxifolia fruit against antitubercular drugsinduced hepatotoxicity in rats. Bangladesh J Pharmacol. 2016; 11: 248-56.

Wang M, Sun J, Jiang Z, Xie W, Zhang X. Hepatoprotective effect of kaempferol against alcoholic liver injury in mice.
Am J Chin Med. 2015; 43: 241-54.

Weng CJ, Chen MJ, Yeh CT, Yen GC. Hepatoprotection of quercetin against oxidative stress by induction of metallothionein expression through activating MAPK and PI3K pathways and enhancing Nrf2 DNA-binding activity. New Biotechnol. 2011; 28: 767-77. 